\title{
GIS and Remote Sensing in Urban Development Planning: Issues and Challenges of Developing World
}

\author{
Dr. Akhilendra Nath Tiwary \\ Senior Lecturer and Head, Department of Geography, Yobe State University, Damaturu, Yobe, Nigeria
}

\begin{abstract}
Urban Planning involves objective or target based process adopted for sustainable urban development. It involves analyzing and predicting the urban environment quantitatively and qualitatively to identify and evaluate alternative policy options leading to a beautiful urban living environment. The quantitative increase in the number of urban centers and populations do not suffice the goal of planning [1]. In the developing countries in spite of the increase in the number of cities and the urban population, quality of urban life is sub standard. For a good quality of life in the cities, smart planning is required. Here GIS (Geographical Information System), GPS (Global Positioning System) and RS (Remote Sensing) come handy as necessary tools and techniques in urban development planning. The digital maps prepared with the help of such modern techniques are scale free. Thus, they can be superimposed to study physical, social, cultural and economic phenomena. The lack of capital and skilled human resource in the use of new technology of GIS, GPS and Remote Sensing in the developing or under developed world is making things difficult. All the softwares and hardwares required by them are imported from developed countries which are less user friendly and developing world is totally dependent on developed world for any technical assistance. An attempt has been in this research paper to discuss the issues and challenges encountered in adoption of the modern tool and techniques of GIS, GPS and Remote Sensing in better planning for the urban development in developing world.
\end{abstract}

Keywords: Sustainable urban development, GIS (Geographical Information System), GPS (Global Positioning System), RS (Remote Sensing), urban planning, developing world

\section{Introduction}

Cities are nodal points for socio economic activities. They create job opportunities and other means of livelihood. In developed world, urban development rates are constant or decline due to regular settlement patterns and relatively stable population. In contrast, developing countries are still industrializing and urbanizing, so they are just beginning to face the additional challenge of making their development sustainable for the long-term [2]. Urban Planning involves objective or target based process adopted for urban development. It involves analyzing and predicting the urban environment quantitatively and qualitatively to identify and evaluate alternative policy options leading to a beautiful life. The feedback mechanism of the planning process ensures sustainable urban development (Fig. 1) A good research methodology adopted in urban geography provides a dynamic platform for the sustainable living environment. The research methodology adopted for studying the cities require both historical and scientific techniques. Urban development plan requires a multidisciplinary approach involving the specialized people from the diverse field of development planning, management, engineering, architecture, economics, accounts, history, sociology, geography, environment, policy formulation, public administration, statistics, demography, law, psychology, computer sciences, Information and communication technology etc. In order to understand the need of the city, a humanistic approach is required to understand the people their problems and requirements.

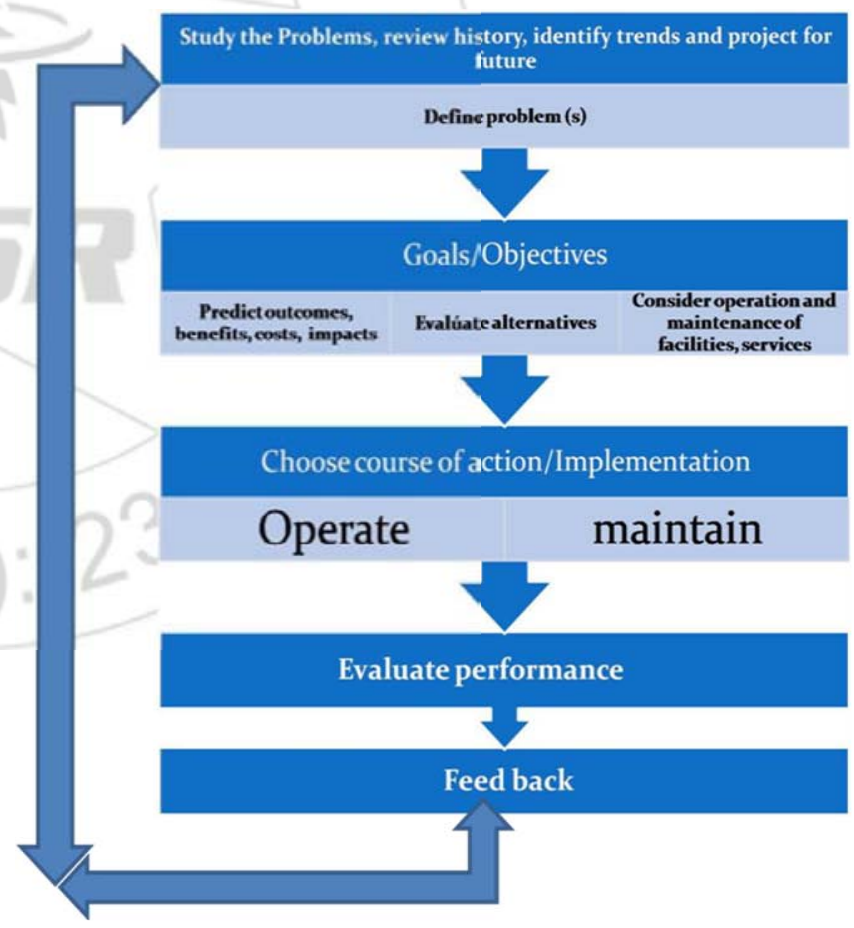

Figure 1: Urban Development Planning Process

\section{GIS and Remote Sensing in Urban Development Planning of Developing World}

GIS and Remote Sensing are modern tools and techniques for efficiently working in urban development planning with some limitations of unavailability and inefficiency of reliable data. The digital maps thus prepared are scale free which can be superimposed to study physical, social, cultural, economic 


\section{International Journal of Science and Research (IJSR) \\ ISSN (Online): 2319-7064}

Index Copernicus Value (2013): 6.14 | Impact Factor (2015): 6.391

and other phenomena. The use of satellite imageries, topographical maps and aerial photographs of different time frames are digitized to get the vector image of the area. The attribute data are attached with the help of database management softwares with such vector images providing platform for spatio temporal analysis of different features as; topography, demography, socio-economic landscapes, etc. (Fig.2). The whole exercise requires highly skilled manpower and capital, their lacking in developing/under developed world is making things difficult. Usually they are not very user friendly and they are imported from developed world. Thus the developing world is totally dependent on developed world for any technical assistance.

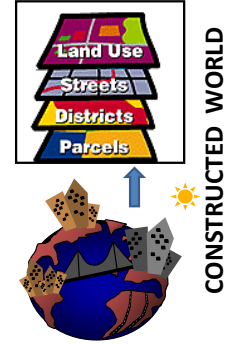

Decision Making And Planning

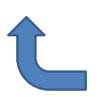

Development Planning

\section{Key Issues and Challenges}

The urban development planning in developing world has numerous issues and challenges spanning from high population growth, lack of skilled work force, poverty, financial crisis, conflicts, basic urban amenities, lack of sustainability etc. The key issues, challenges and proposals may be discussed under the following headings:

\section{a) High Population Growth and Urbanization}

Among the top ten Countries in terms of population, 7 are in developing world. Out of 6.9 Billion of world population 50.40 percent lie in only these seven Countries. Africa has a growth rate of 2.6 percent annually followed by Asia 2.3 per Source: Global Proportion of Population Increase, UN Population Division cent and America 2.1 per cent. Europe has a rate below 1 percent. The future population increase in developing world is going to raise serious issues and challenges of basic amenities, and facilities (Table1). With growing urbanization, more than half of the world population has become urban which is likely to cross more than $60 \%$ in next 15 years. The rate of increase is more in developing world than the developed (Table 2, Fig. 3). The urban population of Africa and Asia is expected to double between 2000 and 2030 [3]. Migration also promotes urban growth in developing countries as people move from the rural areas to cities searching for better job opportunities and quality of life. According to Hall (2005), Between 2000 to 2025, the world's population will double [4]. It means the provision of quality of life for such a large urban population would pose challenges to the developing world as they lack capital for infrastructure development and skilled human resource.

Table 1: Top Countries with over 100 million Population by

\begin{tabular}{|c|c|c|c|}
\hline S.N & Country/area & $\begin{array}{c}\text { Population (in } \\
\text { million) (1 } \\
2013)\end{array}$ & $\begin{array}{c}\text { Population } \\
\text { Growth Rate per } \\
\text { annum (\%) } \\
(2005-10)\end{array}$ \\
\hline- & World & 7,162 & 1.17 \\
\hline 1 & China & 1,385 & 0.48 \\
\hline 2 & India & 1,252 & 1.46 \\
\hline 3 & United States & 320 & 0.97 \\
\hline 4 & Indonesia & 249 & 1.19 \\
\hline 5 & Brazil & 200 & 1.26 \\
\hline 6 & Pakistan & 182 & 1.84 \\
\hline 7 & Nigeria & 173 & 2.27 \\
\hline 8 & Bangladesh & 156 & 1.67 \\
\hline 9 & Russia & 142 & -0.51 \\
\hline 10 & Japan & 127 & -0.02 \\
\hline 11 & Mexico & 122 & 1.12 \\
\hline
\end{tabular}

Source: World Population Prospects (2013), the 2012 Revision.

Table 2: Urban Population of the world \{19002030(Projected) $\}$

\begin{tabular}{|c|c|c|}
\hline Year & Urban Population (million) & Percentage of total \\
\hline 1900 & 220 & 13 \\
\hline 1950 & 732 & 29 \\
\hline 2005 & 3200 & 49 \\
\hline 2030 & 4900 & 60 \\
\hline
\end{tabular}




\section{International Journal of Science and Research (IJSR)}

ISSN (Online): 2319-7064

Index Copernicus Value (2013): 6.14 | Impact Factor (2015): 6.391

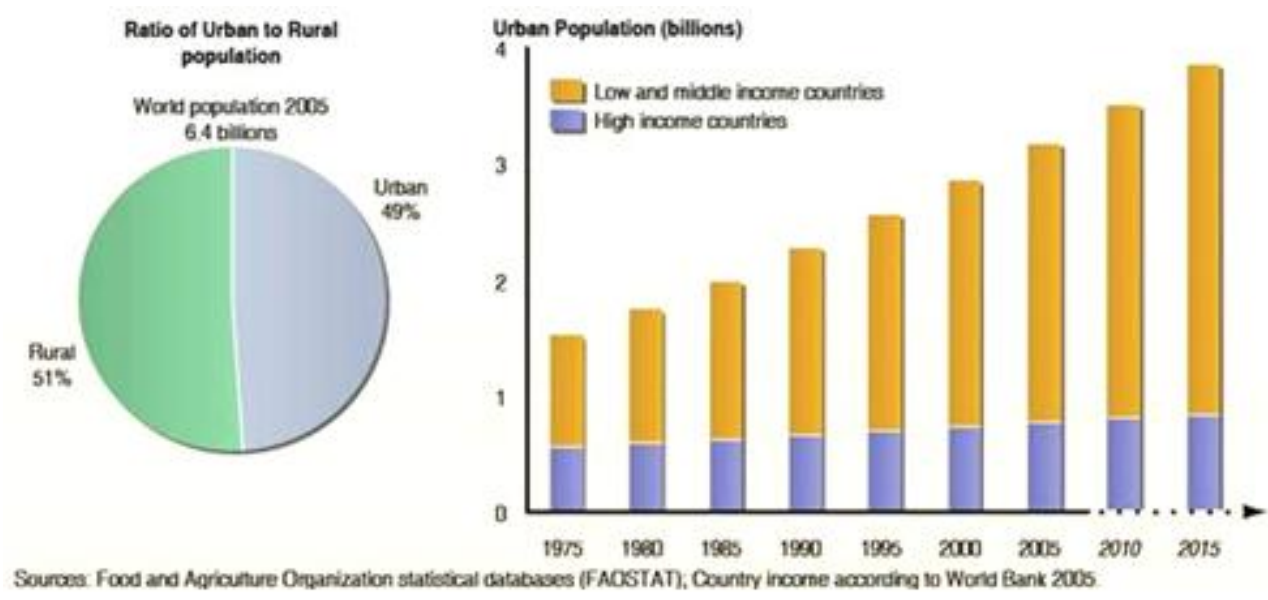

Figure 3: Urban Population trend among Developed (High Income Countries) and Developing World (Middle and Low Income Countries) from 1975

\section{b) Rise of Million and Mega Cities}

All over the world, cities are increasing in size and number. In 1951, New York was the only Mega city (population above 10 million) in the world, by 1990 it was 10 which rose to 30 in 2016 with 453 million urban dwellers residing in them [5]. In 1800 there were only 2 million cities in the world, which rose to 12 in 1900 and 58 in 1950. By 2007, there were 408 million cities in the world. By 2030, UN predicts that there will be more than 500 million cities in the world. In addition, the periurban areas in many big cities are rapidly expanding. Today 22 out of 30 megacities and 290 out of 408 million cities are in developing world. The growing number of these cities in Asia and Africa show a sign of very high urban development. They are also posing challenges to the government and planning agencies. Government, public and developers have to work together to face these challenges as they are beyond control of anyone and require huge financial investments.

\section{c) Urban Poverty and Slums}

The first goal of Millennium Development Goal (MDG) was to eradicate extreme poverty by 2012. But, it failed in the developing world. Due to regular migration from rural to urban areas, the number of urban poor is increasing resulting in more slums and squatter settlements. Almost $25 \%$ of Asia's urban population is poor. Another Millennium Development Goal was to improve significantly the lives of at least 100 million slum dwellers by 2020 [6]. These are posing serious threat to the quality of life and sustainable living environment.

\section{d) Basic Urban Infrastructure Facilities and Amenities}

Large number of the cities in developing world cannot adequately provide urban Infrastructure Facilities and basic services to the increasing number of urban residents. The provisions of drinking water, electricity, sewage, drainage, solid waste management are highly inadequate. There exists an enormous gap between demand and capacity to finance the infrastructure facilities and services. Their building, operation and maintenance require huge investments. It is impossible for any government to manage with the municipal taxes or only government funds. They seek loan, aid or grant from national and international financial institutions as world bank, IMF, ADB etc. But, such loans or grants come with some terms and conditions which are more inflationary. Physical infrastructure planning involves transport and communication in the form of roads, railways, air ways, water ways, flyovers and their terminal facilities. The basic infrastructure in the form of regular electric power supply and installation of more power grids, dams, power plants and transmission networks are required. Education and Health are two such sectors which decide the quality aspect of development. Health GIS and Education GIS have now developed as very useful tools to provide solutions in these regards. Use of GIS and RS in physical planning covering infrastructure facilities, amenities, health and education is the need of the hour. Locational Analysis for all the basic urban facilities and amenities has to be done with the help of GIS and Remote Sensing

\section{e) Public Administration}

Decentralization of the power and coordination among the different agencies is the need of the hour. There is serious lacking in coordination among different urban agencies as; municipality, water board, public works department, land and survey, environment, revenue etc. Collaboration between the central and local governments also lack everywhere in these countries. It can be done smartly with adoption of municipal GIS with database management system. Since last two-three decades, many governments have decentralized responsibilities to local governments on this line. A lot of efforts still to be done in the developing world. Government can ensure that the needs, customs, urban forms, social priorities, and environmental conditions of the local area are reflected in local plans for urban development. But local authorities have not been given the political power, decision making capacity, and access to revenues needed to carry out their functions. This leads to frustration, to continuing criticism of local government for insufficient and inefficient services, and to a downward spiral of weakness feeding on weakness [7]. There is huge shortage of skilled human resource in revenue, tax and octroi data management, Database management of all the citizen and urban facilities in the developing world. E-Revenue GIS is required which 


\section{International Journal of Science and Research (IJSR) \\ ISSN (Online): 2319-7064}

Index Copernicus Value (2013): 6.14 | Impact Factor (2015): 6.391

can be used for calculation, collection and management of revenue system with more authenticity.

\section{f) Responding to globalization}

Globalization has posed challenges to the cities to become globally more competitive. The cities in developing world have not taken advantage of globalization with exception of ASEAN countries, China, India, Brazil and South Africa (IBSA). The development is not satisfactory in Africa, owing to issues related to peace and security. Political instability in the cities of Africa hinder development. Here all the natural resources, site and situation factors are available for fast growth. Due to some veteran interests, political instability is created to take control on these resources. Adoption of GIS and RS can be seen concentrated in few globally connected cities of the developing world. Concentration of economic activities in cities is considered especially efficient in a time of globalization with the case that it should adopt the modern tools and techniques of GIS and RS [8].

\section{g) Formulation, Implementation and Monitoring of Urban Development Plan}

The urban development plan should move forward to the use of survey and collection of remote sensing data on urban land use planning covering residential, industrial, mixed built up areas, recreational, public and semi public, transport \& communications, public utilities and facilities, commercial, reclaimed land, vacant land, vegetated area etc. The study of urban sprawl, urbanization, future projection for urban growth, optimum spatial planning for the core and periphery of the city, network analysis, urban environment analysis, etc., can easily be done with GIS and remote sensing. Several cities across the region have formulated development strategies based on long-term visions and an analysis of their strengths, weaknesses, opportunities and threats. Cities recognized the essential link and Complimentarity between national development policies and city development strategies. The planning process suffers largely at the stage of implementation. It leads to unsustainable changes of layout plans, conversion of reserved lands to other uses than the one proposed on master plan and failure to follow urban planning regulations. The effect of these problems is the emergence of blighted urban centre with very unhygienic living condition [9]

\section{h) Rural-Urban Collaboration}

There is a growing appreciation for the linkages between rural and urban areas. Therefore, any planning should focus on city-regions as a unit for integrated urban development removing the traditional distinction of "rural" and "urban". Both have co-existence in terms of resources, services and existence. While the rural areas supply the food items and labour to the city, the cities in turn supply rural areas with high value consumer goods and services as cloths, diversified food, beverages, vehicles, electrics \& electronic appliances, banking, legal, consultancy, health , education, entertainment and many business services. Urban food prices, held low by subsidies, have served to attract many of them to cities [10]. The use of GIS and Remote Sensing in urban development planning of developing world to promote indigenous knowledge and art at the urban level, while organic and fresh food, vegetables, fruits, milk and poultry should be provided by rural to urban areas without any fraudulent and adulteration. Specific Agro commercial centre equipped with internet and facilities of GIS and RS can be started for each city-region unit. It can be termed as AGRI GIS centre. No Country can deny it for its limited use, lack of fund or expertise. It is better to rise to occasion and involve more geographers who have better knowledge of spatio-temporal and cartographic analysis than any other experts from the fields of science, engineering or social sciences. Ironically the governments in developing countries go to the developed world or to world bank, IMF or any bank of the developed Countries begging for money. They forget that with such loans and financial helps the terms and conditions are also imported which in future play with their security and sovereignty. It is always fair to be self dependent and develop own system of planning and involve planners who can apply the knowledge of Geoinformatics for the welfare of society. It is important to partner with private sector, other cities, and organizations to exchange information, build capacities, expand resources and enhance revenues, and implement improvements in urban management. This would really help the cities to break a nexus of corrupt politicians, bureaucrats, builders and land mafia. Presently they decide the pace and direction of urban development in the developing world. Involvement of local people and adoption of community based development planning is required which would provide more suitability to the local area based demands and necessities. The most significant role in the public administration is the active role of the people. There is need to have public participation at different levels of development plan, right from formulation to its implementation and also its review [11]. It will take some time before GIS and remote sensing can effectively be used in urban development planning in the developed world. The effective introduction of GIS in planning greatly depends on organizational and institutional arrangements, political and top management support and commitment, technical and managerial skills and resources [12] The major problems in the use of GIS and Remote Sensing are; absence of spatial database, Non-uniformity of database on scale and measurement, accuracy of database, difference in attribute, Integration of information and above all the reliability of spatial and attribute data. In the planning the use of modern tools and techniques of Remote Sensing (RS), Geographical Information System (GIS), Global Positioning System, etc. are required. The use of computer, survey analysis softwares (as; SPSS, NUD*ST) and Mapping Softwares (ARC GIS, Map Info, ERDAS, GEOMEDICA etc.) are the need of the hour [13]. The problem would be solved with time and training to the persons involved in this field along with the sincere efforts of the governments to adopt them in planning.

\section{References}

[1] Tiwary, A.N. (2014b). "Urban Development of Northern Nigeria: A Case Study of Nguru In Yobe State", International Journal of Advance Research in 
Management and Social Sciences, Vol.3, Issue 6, June 2014, p. 174

[2] Kiamba, A. (2012).“ The Sustainability of Urban Development in Developing Economies”, Consilience: The Journal of Sustainable Development Vol. 8, Issue 1 (2012), Pp. 20-25

[3] United Nations Department of Economic and Social Affairs (2014) 'World Population Prospects' Population Division, Population Estimates and Projections Section. www.un.org/en/development/.../world-urbanizationprospects-2014.html

[4] Hall, P. (2005). "Land, Shelter and Transport: The Latin America Way", World Bank/IPEA Urban Research Symposium, Brasilia

[5] World Urbanization Prospects (2014) downloaded from http://www.un.org/en/development/desa/news/populatio n/world-urbanization-prospects-2014.html

[6] Bolay, J.C. (2005). "Millennium Goals: Major Challenges for Urban Development", urban news, No.12, Dec. 2005, p.1

[7] Selego, J. (NGO Committee on Education) (1986). "Our Common Future, Chapter 9: The Urban Challenge", A/42/427,Report of the World Commission on Environment and Development. Pt.36, P.7

[8] Yusuf, S., Simon E. and Weiping W. (2001). "Facets of Globalization, International and Local Dimensions of Development", World Bank Discussion Paper No 415, Washington

[9] Tiwary, A.N. (2014a) "Issues and Challenges in Sustainable Urban Development: A Case Study of Mirzapur City, U.P., India”, GE- International Journal of Management Research, Vol.-2, Issue-6, June, 2014, p. 91

[10] Hardoy, J.E. and Satterthwaite. D. (eds.) (1986), Chapter 8: Small and Intermediate Urban Centres; Their role in Regional and National Development in the Third World, London: Hodder and Stoughton.

[11] Tiwary, A.N. (2011b). An Appraisal of Urban Development and Histogenesis: A Case Study of Mirzapur City (ISBN No. 978-3-8443-0167-0), Lambert Academic Publishing GmbH \& Co. KG, Saarbrücken, Germany, printed in USA pp. 91-92

[12] Anthony G. (1991). "The Development and Application of Geographical Information Systems for urban and regional planning in the developing countries", International Journal of Geographical Information Systems, 5:1, p.25

[13] Tiwary, A.N. (2011a). An Appraisal of Urban Development and Planning of Mirzapur City [Ph.D thesis published] (ISBN No. 978-3-639-35917-6), Verlag Dr. Müller Pub., Germany, p.128. 